\title{
Forage and Seed Yield Variation of Alfalfa Cultivars in Response to Planting Date
}

\author{
El-Hifny, M.Z. ${ }^{1}$, B.R. Bakheit ${ }^{1}$, M.S. Hassan ${ }^{2}$ and W.A. Abd El-Rady ${ }^{2}$ \\ 1. Department of Agronomy, Faculty of Agriculture, Assiut University, Assiut, Egypt. \\ 2. Department of Agronomy, Faculty of Agriculture, South Valley University, Qena, Egypt.
}

\begin{abstract}
The current work was carried out during 2014/15 and 2015/16 seasons at the Experimental Farm of Agriculture Faculty, South Valley University, Qena Governorate, Egypt to study the direct and indirect effects of yield attributes on forage and seed yields of alfalfa. Six alfalfa genotypes from Egypt (Aswan population, Balady population, El-Dakhla population, Ismalia-1 cultivar, and nitrogen fixing population and Siwa population) beside one variety from USA (Genan) were used in this study. The experiments were laid out in randomized complete block design using split plot arrangement with three replications. Three sowing dates of $20^{\text {th }}$ October (D1), $20^{\text {th }}$ November (D2) and $20^{\text {th }}$ December (D3) were allocated in the main plot while the seven alfalfa genotypes were arranged in the sub plots. Three cuts were taken from each sowing date at 80, 125 and 165 days after sowing at 80, 45- and 40-day intervals, respectively. After taking three cuts, the plants were left out until flowering and seed production which take place in the first week of April, May and June for studied sowing dates, respectively. The obtained results show that, the Ismalia-1 cultivar exceeded the other tested genotypes for seasonal fresh forage yield trait $\left(6.16 \mathrm{~kg} \mathrm{~m}^{-2}\right)$ under third planting date $\left(20^{\text {th }}\right.$ December $)$ while, El-Dakhla genotype superior with regard to seasonal dry forage yield $\left(2.00 \mathrm{~kg} \mathrm{~m}^{-2}\right)$ under the same planting date. Otherwise, Aswan population produced the maximum mean values of Seasonal protein forage yield $\left(0.60 \mathrm{~kg} \mathrm{~m}^{-2}\right)$ under second planting date $\left(20^{\text {th }}\right.$ November $)$. In addition, Genan cultivar which was introduced from USA gave the maximum seed yield plant $(1.20 \mathrm{~g})$ under the first planting date $\left(20^{\text {th }}\right.$ October $)$. Furthermore, the obtained results show that the fresh forage yield had the greatest influence on protein forage yield in each sowing date. Meantime, the results of path analysis show that, number of seeds/pod and number of pods/plant considered the most effective traits in seed yield/plant of alfalfa. Moreover, negative correlation between seed yield/plant and 1000-seed weight was observed. Therefore, selection for improving seed yield/plant may be carried directly through selection for number of seeds/pod and number of pods/plant.
\end{abstract}

Key words: Alfalfa, path analysis, sowing dates

\section{INTRODUCTION}

Alfalfa or Lucerne (Medicago sativa L.) is cultived mainly for forage and seed yields production. The seed yield is considered to be of only secondary importance.

\footnotetext{
*Corresponding author: M.S. Hassan

Email: elsharany@agr.svu.edu.eg

Received: April 25, 2019;

Accepted: May 6, 2019;

Published: May 7, 2019.
}

The main objectives of the most alfalfa breeding programs are to be increased forage and seed yields. Since it is not possible to achieve genetic progress over the limits determined by existing genes in a population, the choice of germplasm included in a breeding program is a top priority for every breeder (Popovic et al., 2006). Genetic diversity for seed yield and seed yield 
components in alfalfa was described between and within populations by Bolanos-Aguilar et al. (2000). Forage production would benefit from specialization in seed production directed at the consistent, reliable production of heavy yields with high seed quality. According to Rincker et al. (1988), successful alfalfa seed production is favored in regions where the growing season is characterized by low relative humidity and moderate to high temperature. Selection of promising genotypes in a breeding program is based on various criteria, most importantly final crop yield and its components. Relationships between yield and yield contributing traits also play an important role (Diz et al., 1994). Environmental conditions during seed development, genetic characteristics and agronomic techniques have considerable effect on seed yield and components of yield through their effect on plant reproductive.

Path analysis is used to determine the amount of direct and indirect effects of the causal components on the effect component. As previous studies, plant breeders could find well qualified varieties with certain characteristics by using path analysis at the terminal selection stage of breeding. Suleyman and Meryem (2006) found positive direct effect of number of pods per raceme and number of seed per raceme and seed yield of alfalfa and suggested that these yield components may be good selection criteria to improve seed yield of alfalfa cultivars. In contrast, Kowithayakorn \& Hill (1982) and Askarian et al. (1995) found that the number of seeds/pod was an unimportant yield component.

The objective of this study was to identify characteristics induced either by environmental or genetic factors that explain forage and seed yields variation in alfalfa, in terms of forage and seed yields and their components, using path-coefficient analysis to determine the relationships of yield components to one another.

\section{MATERIALS AND METHODS}

Six genotypes from Egypt (Aswan population, Balady population, El-Dakhla population, Ismailia-1 cultivar, Nitrogen fixing population, Siwa population) beside one variety from U.S.A. (Genan) were used for this study. These materials were cultivated at the Experimental Farm, Faculty of Agriculture, South Valley University, Qena governorate, Egypt, during 2014/2015 and 2015/2016 seasons. The physical and chemical properties of the experimental soil in 2014/2015 and 2015/2016 seasons are sand ( 82 and $85 \%)$, silt ( 8 and $11 \%)$, clay (10 and $4 \%)$, soil $\mathrm{pH}(7.7$ and 8$)$ organic matter $(0.17$ and $0.15 \%)$, total $\mathrm{N} \mathrm{mg} / \mathrm{kg}$ (198 and 34) and $\mathrm{CaCO}_{3}(8.5$ and 9.7\%), in the first and second seasons respectively. Climatic data in this location during the study period including maximum and minimum daily temperature and relative humidity, beside photoperiod from sowing date until seed maturity are presented in Table 1 .

\section{Experimental design:}

The experiments were laid out in randomized complete block design using split plot arrangement with three replications. Three sowing dates of $20^{\text {th }}$ October (D1), $20^{\text {th }}$ November (D2) and 20 ${ }^{\text {th }}$ December (D3) were allocated in the main plot while the seven alfalfa genotypes were arranged in the sub plots.

\section{Agricultural practices:}

The sub plot size was one-meter square (3 meters long x $0.33 \mathrm{~m}$ apart). Alfalfa seeds were drilled by hand at the rate of $10.0 \mathrm{~g} / \mathrm{m}^{2}$. Phosphorus was applied at level of 4 grams $\mathrm{P}_{2} \mathrm{O}_{5}$ 15.5\%/plot before seeding. All other cultural practices were done as the 
recommended for alfalfa production. Three cuts were taken from each sowing date at 80 , 125 and 165 days after sowing at 80, 45- and 40-day intervals, respectively. After taking three cuts, the plants were left out until flowering and seed production which take place in the first week of April, May and June for studied sowing dates, respectively.

\section{Data recorded}

\section{Forage yield}

The following traits were recorded at the time of each cut for each sowing date:

1- Seasonal fresh forage yield $\left(\mathrm{kg} / \mathrm{m}^{2}\right)$ : determined by clipping each plot, then total of three cuts were taken for each sowing date. Seasonal dry forage yield $\left(\mathrm{kg} / \mathrm{m}^{2}\right)$ estimated by using, seasonal fresh forage yield of each plot $\times$ mean dry matter percentage, where dry matter percentage was determined from random samples of 150 grams from each plot at each cut, after drying in an oven at $70^{\circ} \mathrm{C}$ until weight constancy.

2- Seasonal protein forage yield $\left(\mathrm{kg} / \mathrm{m}^{2}\right)$ estimated by using seasonal dry forage yield $/ \mathrm{m}^{2} \times$ protein percentage or seasonal fresh forage yield $\times$ mean dry matter percentage $\times$ protein percentage. The protein percentage was determined by micro-kjeldahle method as outlined by A.O.A.C. (2000) to estimate the total nitrogen. Nitrogen percentage was multiplied by 6.25 to obtain crude protein.

\section{Seed yield and its attributes}

At seed maturity stage, the following traits were determined on a sample of 10 plants randomly collected from the center of each plot and for each sowing date: number of pods plant ${ }^{-1}$, number of seeds pod $^{-1}$, thousand seed weight (g.), seed yield plant $^{-1}(\mathrm{~g})$.

\section{Statistical analysis:}

The combined analysis of means for all studied traits were subjected to regular statistical analysis of variance of the randomized complete block design (RCBD)under split plot arrangement according to Gomez and Gomez, (1984). Bartlett test of variance homogeneity was carried out before the combined analysis (Steel et al. 1997). Mean comparison were performed using revised least significant difference (R.L.S.D.) at 5\% level of probability.

\section{Path coefficient analysis}

Path coefficient analysis was done according to the procedure suggested by Dewey and $\mathrm{Lu}$ (1959) for forage yield and its components as well as seed yield and its components, as the following:

Forage yield and its components

First order components of protein forage yield in alfalfa $(\mathrm{Y})$ are:

1- Fresh forage yield (f), 2- mean dry matter percentage $(\mathrm{m}), 3-$ mean protein percentage (t) and residual factors ( $\mathrm{x}$ ) for each sowing date as shown in Figure 1.

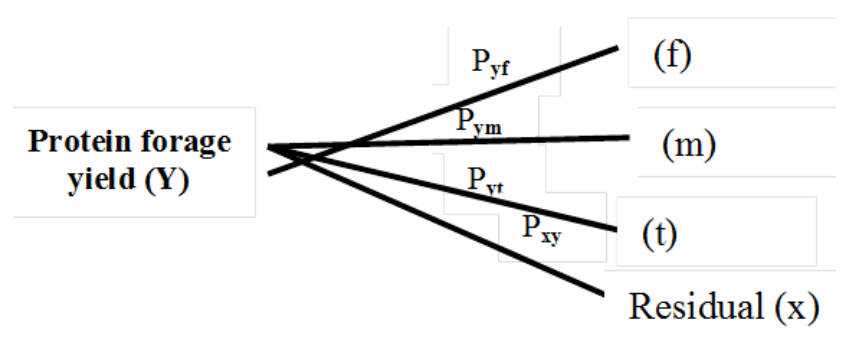

Figure 1. The direct effect and associations of components of protein forage yield and the factors influencing the components.

The correlation coefficients were partitioned into direct and indirect effects as illustrated in the following set of linear equations:

$\mathrm{r}_{\mathrm{yf}}=\mathrm{P}_{\mathrm{yf}}+\mathrm{r}_{\mathrm{fm}} \mathrm{P}_{\mathrm{ym}}+\mathrm{r}_{\mathrm{ft}} \mathrm{P}_{\mathrm{yt}}$ 


$$
\begin{aligned}
& r_{y m}=P_{y m}+r_{f m} P_{y f}+r_{m t} P_{y t} \\
& r_{y t}=P_{y t}+r_{f t} P_{y f}+r_{m t} P_{y m} \\
& 1=P_{x}^{2}+P_{y f}^{2}+P_{y m}^{2}+P_{y t}^{2}+2 P_{y f} r_{f m} P_{m t}+2 P_{y f} r_{f t} P_{m t}+2 P_{y m} r_{m t} P_{y t}
\end{aligned}
$$

Where $r$ is the correlation coefficient between variables, $\mathrm{P}$ is the path coefficient measuring the direct effects, and other is the measure of the indirect effects of one variable upon another.

\section{Seed yield and its components.}

In the same manor, the diagram could be similar for seed yield and its components. Variables of seed yield/plant which were considered to contribute to seed yield/plant (S) were; 1- number of pods/plant, 2- number of seeds/pod, 3- seed index (1000 seed weight) and (X) residual factors.

The path-coefficients in this particular instance were obtained by the simultaneous solution of the above equations.

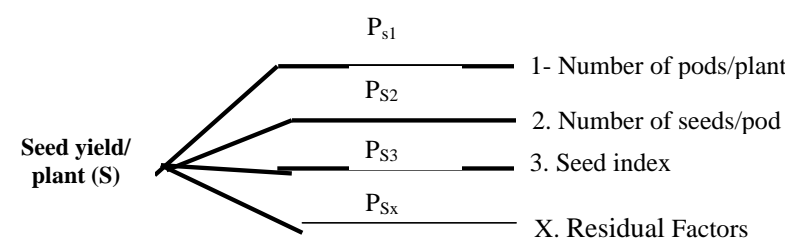

Figure 2.The direct effect and associations of components of seed yield and the factors influencing the components.

$$
\begin{aligned}
& \mathrm{r}_{\mathrm{S} 1}=\mathrm{P}_{\mathrm{S} 1}+\mathrm{r}_{12} \mathrm{P}_{\mathrm{S} 2}+\mathrm{r}_{13} \mathrm{P}_{\mathrm{S} 3} \\
& \mathrm{r}_{\mathrm{S} 2}=\mathrm{P}_{\mathrm{S} 2}+\mathrm{r}_{12} \mathrm{P}_{\mathrm{S} 1}+\mathrm{r}_{23} \mathrm{P}_{\mathrm{S} 3} \\
& \mathrm{r}_{\mathrm{S} 3}=\mathrm{P}_{\mathrm{S} 3}+\mathrm{r}_{13} \mathrm{P}_{\mathrm{S} 1}+\mathrm{r}_{23} \mathrm{P}_{\mathrm{S} 2}
\end{aligned}
$$

Where $r$ is the correlation coefficient between variables, $\mathrm{P}$ is the path coefficient measuring the direct effects, and other is the measure of the indirect effects of one variable upon another.

The path-coefficients in this particular instance were obtained by the simultaneous solution of the above equations.

\section{RESULTS AND DISCUSSION}

\section{Variability and correlation}

The combined analyses of variance for the studied traits over the two seasons are shown in Table 2. Results show that the studied sowing dates, genotypes and their interaction had significant effects on all studied traits except seasonal dry forage yield and 1000seed weight traits which were insignificant. Furthermore, data recorded in Table 3 reveal that the studied traits varied significantly via tested variables. Thus, seasonal fresh forage and protein forage yields, seed yield and its components show the maximum ranges of variation. Moreover, it is clear from the presented data in the Table 3 that the Ismalia1 cultivar exceeded the other tested genotypes for seasonal fresh forage yield trait $\left(6.16 \mathrm{~kg} \mathrm{~m}^{-2}\right)$ under third planting date $\left(20^{\text {th }}\right.$ December) while, El-Dakhla genotype superior with regard to seasonal dry forage yield $\left(2.00 \mathrm{~kg} \mathrm{~m}^{-2}\right)$ under the same planting date. Otherwise, Aswan population produced the maximum mean values of Seasonal protein forage yield $\left(0.60 \mathrm{~kg} \mathrm{~m}^{-2}\right)$ under second planting date $\left(20^{\text {th }}\right.$ November $)$. In addition, Genan cultivar which was introduced from USA gave the maximum seed yield plant $(1.20 \mathrm{~g})$ under the first planting date $\left(20^{\text {th }}\right.$ October). Ibrahim et al. (2015) and Strbanovica et al. (2015) reported that the investigated alfalfa genotypes exhibited high total variability in dry matter yield and crude protein. Here too, the phenotypic correlation among protein forage yield traits under the three sowing dates over the two seasons are shown in 
Table 4. The coefficient of phenotypic correlation under three sowing dates over two seasons between protein forage yield and each of fresh forage yield, dry matter percentage, and protein percentage were $0.250,0.363$ and 0.283 in the first, sowing date being, $0.862,-0.065$ and 0.466 in the second sowing date and $0.935,0.163$ and 0.258 in the third sowing date, respectively. These results indicate that the most effective components in protein forage yield of alfalfa would be fresh forage yield in major issue and dry matter percentage and protein percentage in minor role. The phenotypic correlation among seed yield/plant traits under three sowing dates over two seasons are shown in Table 5. The coefficient of phenotypic correlation under the three sowing dates over the two seasons between seed yield/plant and each of number of pods/plant, number of seeds/pod and seed index were $0.221,0.873$ and -0.351 ; respectively, in the first sowing date being, $0.454,0.872$ and -0.158 , respectively, in the second sowing date over the two seasons. Moreover, correlations over the two seasons under the third sowing dates approximately had the same trend $(0.964,0.758$ and -0.490). These results indicate that the most effective components in seed yield/plant of alfalfa would be the number of seeds/pod and the number of pods/plant. However, there was negative correlation between seed yield/plant and 1000-seed weight. These results are in line with those obtained by Sengul (2006) who found that seed yield was significantly positively correlated with the number of seeds/ inflorescences $(r=0.593)$, number of pods/inflorescence $(\mathrm{r}=0.602)$.

\section{Path-coefficient analysis}

\section{1- Forage yield and its components}

Path-coefficient analysis was used to determine the direct and indirect effects of the fresh forage yield, dry matter percentage and mean protein percentage on protein forage yield under the three sowing dates over the two seasons are presented in Table 4 and Figure 1. Figure (1) is a path diagram showing the direct and indirect influences of protein forage yield components traits for each sowing date. In each sowing date fresh forage yield had the greatest influence on protein forage yield as indicated by phenotypic correlations as well as pathcoefficient analysis. The path-coefficient analysis differed from sowing date to another and among seasons. Also, the pathcoefficient analysis revealed that fresh forage yield contributed most direct effect for each sowing dates over the two seasons (Table 4) but was negative for indirect via dry matter percentage and protein percentage in each sowing date over the two seasons. This may indicate that the fresh forage yield had the major effects in direct contribution toward protein forage yield. To sum, protein forage yield of forage crops could be generally a function of fresh forage yield $\times$ mean dry matter percentage $\times$ mean protein percentage. Direct effect of fresh forage yield on protein forage yield over two seasons were 1.654, 0.952 and 0.937 for the first, second and third sowing dates, respectively. However, its indirect effects via mean dry matter percentage were $-0.574,-0.082$ and -0.037 and via protein percentage were -0.830 , 0.008 and 0.035 . Mean dry matter percentage had positive direct effect $(0.777$, 0.172 and 0.351$)$ and negative indirect effect via fresh forage yield $(-1.223,-0.452$ and 0.097). Moreover, mean protein percentage had a positive direct effect (1.016, 0.391, and $0.255)$ and a negative and positive indirect effect via fresh forage yield $(-1.352,-0.020$ and 0.127 ) and via dry matter percentage 
(0.619, 0.095 and -0.125). It could be concluded that the fresh forage yield, dry matter percentage and protein percentage are important traits for selection of high protein forage yield in alfalfa as a results of direct effect in path-coefficient analysis (Table 4). With this respect, Julier et al. (2000) stated that forage yield and its quality are complex traits whose expression is influenced by genetic constitution of a plant as well as environmental factors. Because of the abovementioned reasons, determining the genetic potential of the alfalfa ecotypes and the interrelation among traits are of high importance. Monirifar (2011) reported that plant dry weight had a positive relation with all other yield components. Also, these results are in line with those reported by Bakheit (1988) and Hamd Alla et al. (2013) in Egyptian clover who found that seasonal fresh forage yield had the highest positive direct effect on seasonal protein forage yield (0.84) followed by mean dry matter percentage (0.46) and protein percentage (0.172).

On the other hand, the residual effect of pathcoefficient for yield trait was negligible in most environments, indicating that there are no other traits not recorded in the research.

\section{2- Seed yield and its components}

Path-coefficient analysis was used to determine the direct and indirect effect of number of pods/plant, number of seeds/pod, and seed index (1000-seed weight) on seed yield/plant (Table 5 and Figure 2). Results show that the relative importance of the primary seed yield components was different from sowing date to another. On the other hand, in this study path-coefficient analysis showed complex interrelations among seed yield components because number of pods/plant, number of seeds/pod, and 1000seed weight were all important in determining seed yield in alfalfa. This means that, seed yield/plant of alfalfa could be generally a function of number of pods/plant $\mathrm{x}$ number of seeds/pod x 1000-seed weight over the two seasons. Direct effects of number of pod/plant on seed yield/plant were $0.511,0.390$ and 0.823 in the first, second and third sowing dates, respectively. While, indirect effects via seed index were; -0.233, 0.047 and -0.070 in the same order. While, the direct effect of number of seed/pod on seed yield/plant were 1.186, 0.997 and 0.359, respectively, but the indirect effect via seed index were $-0.288,-0.168$ and -0.086 at the same order. Also, the direct effect of 1000seed weight on seed yield/plant were 0.526 , 0.359 and 0.141 , respectively, but the indirect effect via number of seeds/pod were $-0.650,-0.466$ and -0.219 . With this respect very little information was available on alfalfa seed yield associations with inflorescences level. A large genetic variation among and within population of alfalfa for seed yield and its component was reported by Campbeil \& He (1997). The seed yield components responded differently to the effect of plant genetics and management techniques (Sengul, 2006). Iannucci et al. (2002) reported complex interactions among seed yield components with inflorescence density, pods/inflorescence, seed/pod and 1000-seed weight. These results are in line with those reported by Sengul (2006). 
Table 1: Summary of some meteorological data during the period of alfalfa growth in $2014 / 2015$ and $2015 / 2016$ seasons.

\begin{tabular}{|c|c|c|c|c|c|c|c|c|c|c|c|c|c|c|c|c|c|c|c|}
\hline \multirow{3}{*}{ Month } & \multirow{3}{*}{$\begin{array}{r}\text { Weather } \\
\text { factor }\end{array}$} & \multicolumn{6}{|c|}{ Average temperature ${ }^{\circ} \mathbf{C}$} & \multicolumn{6}{|c|}{ Average relative humidity \% } & \multicolumn{6}{|c|}{ Sun shine } \\
\hline & & \multicolumn{3}{|c|}{$2014 / 2015$} & \multicolumn{3}{|c|}{$2015 / 2016$} & \multicolumn{3}{|c|}{$2014 / 2015$} & \multicolumn{3}{|c|}{ 2015/2016 } & \multicolumn{3}{|c|}{$2014 / 2015$} & \multicolumn{3}{|c|}{$2015 / 2016$} \\
\hline & & Max. & Min. & Mean & Max. & Min. & Mean & Max. & Min. & Mean & Max. & Min. & Mear & $\begin{array}{l}\text { Sun } \\
\text { rise }\end{array}$ & $\begin{array}{c}\text { Sun } \\
\text { set }\end{array}$ & $\begin{array}{c}\text { Day } \\
\text { length }\end{array}$ & $\begin{array}{l}\text { Sun } \\
\text { rise }\end{array}$ & $\begin{array}{c}\text { Sun } \\
\text { set }\end{array}$ & $\begin{array}{c}\text { Day } \\
\text { length }\end{array}$ \\
\hline \multirow[t]{2}{*}{ Oct. } & $20-31$ & 32.12 & 17.65 & 27.00 & 33.64 & 21.19 & 21078 & 51.00 & 10.42 & J0.11 & 57.25 & 22.25 & 39.75 & $5: 45$ & $17: 13$ & $11: 28$ & $5: 45$ & $17: 13$ & $11: 28$ \\
\hline & 01-10 & 32.07 & 17.33 & 24.70 & 29.31 & 16.60 & 22.96 & 50.17 & 16.08 & 33.13 & 64.52 & 26.19 & 45.35 & $5: 45$ & $17: 12$ & $11: 26$ & $5: 45$ & $17: 12$ & 11:26 \\
\hline \multirow{3}{*}{ Nov. } & 11-20 & 29.38 & 14.94 & 22.16 & 21.34 & 7.43 & 14.38 & 48.33 & 15.25 & 31.79 & 75.49 & 28.75 & 52.12 & $5: 49$ & $17: 11$ & 11:21 & $5: 51$ & 17:11 & 11:19 \\
\hline & 21-30 & 24.96 & 12.1 & 18.53 & 27.92 & 13.29 & 20.61 & 47.92 & 14.58 & 31.25 & 71.37 & 26.65 & 49.01 & $5: 54$ & $17: 10$ & 11:16 & $5: 54$ & $17: 10$ & 11:16 \\
\hline & 01-10 & 28.23 & 14.42 & 21.325 & 24.48 & 10.42 & 17.45 & 72.30 & 29.60 & 49.60 & 71.86 & 23.30 & 47.58 & $5: 54$ & 17:09 & 11:14 & $5: 54$ & $17: 09$ & 11:14 \\
\hline \multirow[t]{3}{*}{ Dec. } & $11-20$ & 25.58 & 12.00 & 18.79 & 21.93 & 9.12 & 15.53 & 71.20 & 28.20 & 51.15 & 81.49 & 30.44 & 55.97 & $5: 55$ & 17:09 & 11:13 & $5: 55$ & 17:09 & 11:13 \\
\hline & 21-31 & 22.85 & 8.50 & 15.68 & 22.35 & 8.41 & 15.38 & 75.27 & 25.00 & 49.05 & 73.87 & 27.04 & 50.46 & $5: 56$ & 17:08 & 11:12 & $5: 56$ & $17: 08$ & 11:12 \\
\hline & 01-10 & 18.52 & 6.26 & 12.39 & 21.34 & 7.43 & 14.38 & 66.90 & 27.10 & 48.15 & 75.49 & 28.75 & 52.12 & $5: 56$ & 17:07 & 11:10 & $5: 56$ & $17: 07$ & 11:10 \\
\hline \multirow[t]{3}{*}{ Jan. } & $11-20$ & 20.86 & 6.03 & 13.445 & 22.35 & 7.83 & 15.09 & 68.00 & 25.30 & 44.40 & 75.87 & 27.56 & 51.72 & $5: 57$ & 17:07 & 11:09 & $5: 57$ & 17:07 & 11:09 \\
\hline & 21-31 & 26.95 & 10.63 & 18.79 & 18.63 & 5.85 & & 52.64 & 20.64 & 36.91 & 74.41 & 30.13 & 52.27 & $5: 58$ & 17:06 & 11:08 & $5: 58$ & 17:06 & 11:08 \\
\hline & 01-10 & 27.03 & 9.57 & 18.30 & 22.54 & 8.43 & 15.49 & 51.30 & 16.90 & 34.05 & 67.70 & 24.01 & 45.86 & $5: 58$ & $17: 05$ & 11:07 & $5: 58$ & $17: 05$ & 11:07 \\
\hline \multirow[t]{3}{*}{ Feb. } & $11-20$ & 21.72 & 9.45 & 15.59 & 28.33 & 11.20 & 19.77 & 51.92 & 18.33 & 35.13 & 52.73 & 16.50 & 34.61 & $5: 59$ & $17: 05$ & 11:06 & $5: 59$ & $17: 05$ & 11:06 \\
\hline & 21-29 & & 12.16 & & 27.38 & & & & & & & 18.38 & & 6:00 & & 11:05 & 6:00 & 05 & 11:05 \\
\hline & 01-10 & 30.14 & 14.07 & 22.105 & 30.60 & 14.60 & 22.60 & 53.70 & 13.70 & 33.15 & 47.55 & 12.80 & 30.30 & $6: 00$ & 17:04 & 11:03 & 6:00 & $17: 04$ & 11:03 \\
\hline \multirow[t]{3}{*}{ Mar. } & $11-20$ & 28.28 & 13.82 & 21.05 & 29.98 & 17.04 & 23.51 & 59.30 & 15.10 & $\mathbf{3 7 . 3 0}$ & 47.89 & 12.29 & 30.10 & 6:01 & 17:04 & 11:02 & 6:01 & 17:04 & 11:02 \\
\hline & 21-31 & 32.22 & 17.34 & 24.78 & 30.65 & 16.21 & 23.43 & 33.45 & 9.18 & 21.55 & 44.91 & 12.64 & 28.78 & $6: 02$ & $17: 03$ & 11:01 & $6: 02$ & $17: 03$ & 11:01 \\
\hline & 01-10 & 32.15 & 16.33 & 24.24 & 35.80 & 19.12 & 27.46 & 36.40 & 9.70 & 23.05 & 35.92 & 8.90 & 22.41 & 6:02 & 17:02 & 11:00 & $6: 02$ & 17:02 & 11:00 \\
\hline \multirow[t]{3}{*}{ Apr. } & $11-20$ & 28.97 & 13.68 & 21.33 & 34.58 & 19.57 & 27.07 & 29.78 & 9.56 & 19.67 & 35.30 & 8.99 & 22.15 & $6: 03$ & 17:02 & 10:58 & 6:03 & $17: 02$ & $10: 58$ \\
\hline & 21-30 & 36.35 & 18.70 & 27.53 & 38.47 & 21.90 & 30.18 & 29.30 & 6.20 & 19.20 & 28.56 & 6.00 & 17.82 & $6: 04$ & 17:02 & 10:57 & 6:04 & 17:02 & $10: 57$ \\
\hline & 01-10 & 36.21 & 20.62 & 28.42 & 38.11 & 22.81 & 30.46 & 36.40 & 9.70 & 23.05 & 28.66 & 7.69 & 18.22 & 6:04 & 17:01 & $10: 56$ & 6:04 & 17:01 & $10: 56$ \\
\hline \multirow[t]{3}{*}{ May } & $11-20$ & 36.70 & 21.60 & 29.15 & 41.01 & 24.31 & 32.66 & 29.78 & 9.56 & 19.67 & 26.97 & 5.75 & 16.36 & $6: 05$ & 17:01 & $10: 55$ & $6: 05$ & 17:01 & $10: 55$ \\
\hline & $21-31$ & 40.52 & 25.21 & 32.86 & 37.53 & 22.68 & 30.10 & 26.08 & 6.50 & 16.29 & 33.00 & 6.37 & 19.68 & 6:05 & $17: 00$ & 10:55 & 6:05 & $17: 00$ & $10: 55$ \\
\hline & 01-10 & 40.90 & 24.85 & 32.875 & 43.74 & 27.94 & 35.00 & 28.70 & 7.00 & 17.50 & 22.92 & 5.34 & 14.13 & 6:06 & $17: 00$ & $10: 54$ & 6:06 & $17: 00$ & $10: 54$ \\
\hline \multirow{3}{*}{ Jun. } & $11-20$ & 39.62 & 24.98 & 32.30 & 42.41 & 26.28 & 34.27 & 35.50 & 7.50 & 21.55 & 30.84 & 7.33 & 19.50 & 6:07 & 16:59 & $10: 52$ & 6:07 & 16:59 & 10:52 \\
\hline & $21-30$ & 38.47 & 25.15 & 31.81 & 42.30 & 27.71 & 35.00 & 36.10 & 9.10 & 22.95 & 32.99 & 8.36 & 21.46 & 6:07 & 16:59 & 10:51 & 6:07 & $16: 59$ & $10: 51$ \\
\hline & 01-10 & 39.12 & 24.61 & 31.87 & 40.56 & 27.01 & 33.79 & 39.50 & 11.3 & 25.55 & $\mathbf{3 7 . 3 1}$ & 11.18 & 24.30 & $6: 08$ & 16:59 & $10: 50$ & $6: 08$ & 16:59 & $10: 50$ \\
\hline \multirow[t]{2}{*}{ Jul. } & $11-20$ & 39.99 & 25.57 & 32.78 & 40.48 & 26.80 & 33.64 & 37.20 & 9.90 & 22.35 & 33.72 & 11.01 & 22.37 & 6:09 & 16:59 & $10: 49$ & 6:09 & 16:59 & $10: 49$ \\
\hline & 21-31 & 42.22 & 26.88 & 34.55 & 40.76 & 26.22 & 33.49 & 29.64 & 8.90 & 19.60 & 37.82 & 11.23 & 24.53 & 6:09 & $16: 58$ & $10: 48$ & 6:09 & $16: 58$ & $10: 48$ \\
\hline
\end{tabular}

Source: Meteorological authority, Qena, Egypt 
Table 2: Combined analysis of variance for forage and seed yields and its components of seven alfalfa genotypes under three different sowing dates over the two seasons.

\begin{tabular}{|c|c|c|c|c|c|c|c|c|}
\hline \multirow{3}{*}{ Source of variation } & \multirow{3}{*}{ 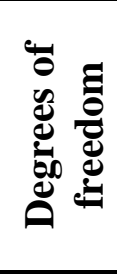 } & \multicolumn{7}{|c|}{ Mean Squares } \\
\hline & & \multicolumn{3}{|c|}{ Forage traits } & \multicolumn{4}{|c|}{ Seed traits } \\
\hline & & $\begin{array}{c}\begin{array}{c}\text { Seasonal fresh } \\
\text { forage yield } \\
\left(\mathrm{kg} / \mathrm{m}^{2}\right)\end{array} \\
\end{array}$ & $\begin{array}{c}\text { Seasonal dry } \\
\text { forage yield } \\
\left(\mathrm{kg} / \mathrm{m}^{2}\right) \\
\end{array}$ & $\begin{array}{c}\text { Seasonal } \\
\text { protein forage } \\
\text { yield }\left(\mathrm{kg} / \mathbf{m}^{2}\right)\end{array}$ & $\begin{array}{l}\text { Number of } \\
\text { pods/plant }\end{array}$ & $\begin{array}{l}\text { Number of } \\
\text { seeds/pod }\end{array}$ & $\begin{array}{l}1000 \text { seed } \\
\text { weight }(\mathrm{g})\end{array}$ & $\underset{\text { (g) }}{\text { Seed yield/ plant }}$ \\
\hline Year $(Y)$ & 1 & $40.05^{* *}$ & $7.72 * *$ & $0.46^{* *}$ & $1594.5^{* *}$ & $49.87 * *$ & $1.64 * *$ & $1.19 * *$ \\
\hline Error (a) & 4 & 0.99 & 0.02 & 0.003 & 57.32 & 0.31 & 0.01 & 0.03 \\
\hline$Y \times D$ & 2 & 0.49 & 0.20 & 0.01 & $700.45 * *$ & $7.61 * *$ & $1.57 * *$ & 0.06 \\
\hline Error (b) & 8 & 1.30 & 0.89 & 0.06 & 58.43 & 0.92 & 0.05 & 0.04 \\
\hline Genotypes (G) & 6 & $15.30 * *$ & $1.03 *$ & $0.09 * *$ & $475.65^{* *}$ & $8.65 * *$ & $0.33 * *$ & $0.27 * *$ \\
\hline $\mathbf{G} \times \mathbf{Y}$ & 6 & $3.09 * *$ & 0.16 & 0.008 & $442.25 * *$ & 0.91 & $0.23 * *$ & $0.11^{* *}$ \\
\hline$G \times D \times Y$ & 12 & $1.77 * *$ & $0.22 * *$ & 0.01 & $223 * *$ & $5.01 * *$ & $0.51 * *$ & $0.09 * *$ \\
\hline Error (c) & 72 & 0.43 & 0.10 & 0.007 & 67.11 & 0.84 & 0.03 & 0.03 \\
\hline
\end{tabular}

$*$, ** Significant at 0.05 and 0.01 levels of probability, respectively. 
Table 3: Means of the studied traits over the two seasons for the seven alfalfa genotypes under the three sowing dates.

\begin{tabular}{|c|c|c|c|c|c|c|c|c|}
\hline $\begin{array}{c}\text { Sowing } \\
\text { dates }\end{array}$ & Genotypes & $\begin{array}{l}\text { Seasonal fresh } \\
\text { forage yield } \\
\left(\mathrm{kg} / \mathrm{m}^{2}\right)\end{array}$ & $\begin{array}{l}\text { Seasonal dry } \\
\text { forage yield } \\
\quad\left(\mathrm{kg} / \mathbf{m}^{2}\right)\end{array}$ & $\begin{array}{l}\text { Seasonal protein } \\
\text { forage yield } \\
\left(\mathrm{kg} / \mathrm{m}^{2}\right)\end{array}$ & $\begin{array}{l}\text { Number of } \\
\text { pods/plant }\end{array}$ & $\begin{array}{l}\text { Number of } \\
\text { seeds/pod }\end{array}$ & $\begin{array}{l}1000 \text { seed } \\
\text { weight }(g)\end{array}$ & $\begin{array}{l}\text { Seed yield/ } \\
\text { plant }(g)\end{array}$ \\
\hline \multirow{8}{*}{$\mathbf{D}_{1}$} & Aswan & 5.05 & 1.64 & 0.37 & 54.6 & 4.20 & 2.82 & 0.54 \\
\hline & Balady & 4.50 & 1.52 & 0.32 & 59.4 & 6.35 & 2.70 & 0.96 \\
\hline & El-Dakhla & 4.43 & 1.59 & 0.34 & 56.2 & 5.28 & 2.53 & 0.83 \\
\hline & Ismalia- 1 cultivar & 4.86 & 1.35 & 0.25 & 69.2 & 4.67 & 2.61 & 0.75 \\
\hline & Nitrogen fixing & 4.30 & 1.52 & 0.31 & 70.4 & 4.65 & 2.55 & 0.75 \\
\hline & Genan & 2.86 & 1.26 & 0.29 & 64.1 & 6.57 & 2.39 & 1.20 \\
\hline & Siwa & 4.25 & 1.44 & 0.34 & 62.4 & 6.63 & 2.51 & 0.97 \\
\hline & Aswan & 5.75 & 1.96 & 0.60 & 58.5 & 3.49 & 2.97 & 0.67 \\
\hline \multirow{5}{*}{$\mathbf{D}_{2}$} & Balady & 4.80 & 1.43 & 0.31 & 62.6 & 5.12 & 2.90 & 1.01 \\
\hline & El-Dakhla & 5.71 & 1.78 & 0.51 & 56.3 & 5.89 & 2.53 & 0.74 \\
\hline & Ismalia-1 cultivar & 3.74 & 1.35 & 0.35 & 67.8 & 4.08 & 2.74 & 0.83 \\
\hline & Nitrogen fixing & 3.24 & 1.16 & 0.30 & 67.9 & 4.37 & 2.62 & 0.77 \\
\hline & Genan & 2.28 & 1.07 & 0.24 & 69.5 & 6.53 & 2.68 & 0.92 \\
\hline \multirow{9}{*}{$\mathbf{D}_{3}$} & Siwa & 3.71 & 1.23 & 0.30 & 64.0 & 5.08 & 2.94 & 0.94 \\
\hline & Aswan & 5.69 & 1.94 & 0.47 & 45.5 & 6.06 & 2.07 & 0.58 \\
\hline & Balady & 5.79 & 1.71 & 0.40 & 50.3 & 6.71 & 2.00 & 0.69 \\
\hline & El-Dakhla & 5.92 & 2.00 & 0.44 & 81.0 & 8.18 & 1.66 & 1.11 \\
\hline & Ismalia- 1 cultivar & 6.16 & 1.76 & 0.46 & 54.5 & 6.43 & 1.88 & 0.69 \\
\hline & Nitrogen fixing & 5.68 & 1.72 & 0.40 & 45.7 & 6.90 & 1.82 & 0.58 \\
\hline & Genan & 3.40 & 1.08 & 0.25 & 40.9 & 5.71 & 1.81 & 0.44 \\
\hline & Siwa & 5.01 & 1.58 & 0.39 & 78.0 & 6.14 & 1.88 & 0.89 \\
\hline & S.D. $(\mathrm{D} * \mathrm{G})$ & 0.77 & - & 0.131 & 8.7 & 1.05 & - & 0.19 \\
\hline
\end{tabular}


Table 4: Path coefficient analysis of protein forage yield and its components over the two seasons for the three planting dates.

\begin{tabular}{|c|c|c|c|}
\hline \multirow{2}{*}{ Effect } & \multicolumn{3}{|c|}{ Combined over years } \\
\hline & Date 1 & Date 2 & Date 3 \\
\hline Direct effect of fresh forage yield on protein forage yield & 1.654 & 0.952 & 0.937 \\
\hline Indirect Effect of fresh forage yield on protein forage yield via dry matter $\%$ & -0.574 & -0.082 & -0.037 \\
\hline Indirect effect of fresh forage yield on protein forage yield via protein $\%$ & -0.830 & -0.008 & 0.035 \\
\hline Total indirect effect & -1.404 & -0.090 & -0.002 \\
\hline Correlation between protein forage yield and dry matter \% & 0.363 & -0.065 & 0.163 \\
\hline Direct effect of dry matter \%on protein forage yield & 0.777 & 0.172 & 0.351 \\
\hline Indirect effect of dry matter $\%$ on protein forage yield via fresh forage yield & -1.223 & -0.452 & -0.097 \\
\hline Indirect effect of dry matter $\%$ on protein forage yield via protein $\%$ & 0.810 & 0.215 & -0.091 \\
\hline Total indirect effect of dry matter \% & -0.413 & -0.237 & -0.188 \\
\hline Correlation between protein forage yield and protein $\%$ & 0.283 & 0.466 & 0.258 \\
\hline Direct effect of protein $\%$ on protein forage yield & 1.016 & 0.391 & 0.255 \\
\hline Indirect effect of protein $\%$ on protein forage yield via fresh forage yield & -1.352 & -0.020 & 0.127 \\
\hline Indirect effect of protein $\%$ on protein forage yield via dry matter $\%$ & 0.619 & 0.095 & -0.125 \\
\hline Total indirect effect of protein $\%$ & -0.733 & 0.075 & 0.002 \\
\hline Residual effect & 0.008 & 0.004 & 0.001 \\
\hline
\end{tabular}


Table 5: Path coefficient analysis of seed yield per plant and its components over the two seasons for the three planting dates.

\begin{tabular}{|c|c|c|c|}
\hline \multirow{2}{*}{ Effect } & \multicolumn{3}{|c|}{ Combined over years } \\
\hline & Date 1 & Date 2 & Date 3 \\
\hline Direct effect of number of pods per plant on seed yield per plant & 0.511 & 0.390 & 0.823 \\
\hline Indirect effect of number of pods per plant on seed yield via seed index & -0.233 & -0.047 & -0.070 \\
\hline Indirect effect of number of pods per plant on seed per plant via no. of seeds per pod & -0.056 & 0.111 & 0.211 \\
\hline Total indirect effect of number of pods per plant & -0.289 & 0.065 & 0.141 \\
\hline Correlation between seed index and seed yield per plant & -0.351 & $-\mathbf{0 . 1 5 8}$ & -0.490 \\
\hline Direct effect of seed index on seed yield per plant & 0.526 & 0.359 & 0.141 \\
\hline Indirect effect of seed index on seed yield per plant via no. of seed per pod & -0.650 & -0.466 & -0.219 \\
\hline Indirect effect of seed index on seed per plant via no. of pods per plant & -0.226 & -0.051 & -0.412 \\
\hline Total indirect effect of seed index & -0.877 & -0.517 & -0.631 \\
\hline Correlation between no. of seeds per pod and seed yield per plant & $\mathbf{0 . 8 7 3}$ & 0.872 & 0.758 \\
\hline Direct effect of no of seeds per pod on seed yield per plant & 1.186 & 0.997 & 0.359 \\
\hline Indirect effect of no. of seeds per pod on seed yield per plant via no. of pods per plant & -0.024 & 0.044 & 0.485 \\
\hline Indirect effect of no. of seeds per pod on seed yield per plant via seed index & -0.288 & -0.168 & -0.086 \\
\hline Total indirect effect of no. of seeds per plant & -0.313 & -0.124 & 0.399 \\
\hline Residual effect & 0.018 & 0.005 & 0.002 \\
\hline
\end{tabular}




\section{CONCLUSION}

From the obtained results in this study, there are several genotypes had superior potential for seasonal fresh forage yield, seasonal dry forage yield, Seasonal protein forage yield and seed yield plan traits under different planting dates. Thus, the Ismalia-1 cultivar exceeded the other tested genotypes for seasonal fresh forage yield trait $\left(6.16 \mathrm{~kg} \mathrm{~m}^{-2}\right)$ under third planting date $\left(20^{\text {th }}\right.$ December $)$ while, El-Dakhla genotype superior with regard to seasonal dry forage yield $(2.00 \mathrm{~kg}$ $\mathrm{m}^{-2}$ ) under the same planting date. Otherwise, Aswan population produced the maximum mean values of Seasonal protein forage yield $\left(0.60 \mathrm{~kg} \mathrm{~m}^{-2}\right)$ under second planting date $\left(20^{\text {th }}\right.$ November). In addition, Genan cultivar which was introduced from USA gave the maximum seed yield plant (1.20 g) under the first planting date $\left(20^{\text {th }}\right.$ October). In addition, the results of the path-coefficient analysis suggest that selection for improving seed yield/plant may be carried directly through selection for number of seeds/pod and number of pods/plant.

\section{REFERENCES}

A.O.A.C. (2000) 'Official Methods of Analysis. $13^{\text {th }}$ edu. Association of Official Analytical Chemists'. Washington, D.C.

Askarian, M., Hampton, J.G.and Hill, M.,J. (1995) 'Effect of row spacing and sowing rate on seed production of Lucerne (Medicago sativa L.) $c v^{\prime}$. Grasslands orange, N.Z.J. Agric. Res., 38: 289-295.

Bakheit, B.R. (1988) 'Variation, correlation and path-coefficient analysis in some world varieties of alfalfa (Medicago sativa L)'. Assiut J. of Agric. Sci., 19: 149-163.
Bolaños-Aguilar, E.D., Huyghe ,C., Djukic D., Julier, B. and Ecalle, C. (2000) 'Genetic inheritance of alfalfa seed yield and its components'. Plant Breed. 120: 67-72.

Campbell, T.,A. and He, Y. (1997)' Factorial analysis of self-incompatibility in alfalfa'. Canadian Journal of Plant Science, 77: 69-73.

Dewey, O.,R. and Lu, K.H. (1959) 'A correlation and path coefficient analysis of components of crested wheat grass and seed production'. Agron. J. 51: 515-518.

Diz, D.A., Wofford,D.,S. and Schank, S.,C. (1994) 'Correlation and path coefficient analysis of seed yield components in pearl millet $\mathrm{x}$ elephant grass hybrids. Theor'. Appl. Genet., 89: 112-115.

Gomez, K.A. and Gomez,A.A. (1984)

'Statistical Procedures for Agriculture

Research. A Wiley - Inter Science

Publication'. John wiley sons, lnc. New York, USA.

Hamd Alla, W.A., Bakheit, B.R., AboElwafa, A. and El-Nahrawy, M.,A. (2013)'Evaluate of some varieties of alfalfa for forage yield and its components under the New Valley conditions'. J. of Agroalimentary Processes and Technologies, 19: 413418.

Iannucci, A. Di., Fonzob, N. and Martinielloa ,P. (2002)' Alfalfa (Medicago sativa L.) seed yield and quality under different forage management systems and irrigation treatments in a Mediterranean environment'. Field Crop Res., 78: 6574. 
Ibrahim, H. I. M., Rajab, M.N., Walaa, M.E. and Mervat ,R.I. S. (2015)'Assessment of Genetic Diversity among Egyptian Alfalfa Varieties Using AgroMorphological and Molecular Markers'. Am-Euras. J. Agric. \& Environ. Sci., 15 (6): 1113-1122

Julier, B., Huyghe, C. and Ecalle ,C. (2000)'Within- and among-cultivar genetic variation in alfalfa: forage quality, morphology and yield'. Crop Science, 40: 365-369.

Kowithayakorn, L. and Hill, M.J.( 1982)' A study of herbage and seed production in Lucerne (Medicago sativa L.) under different plant spacing and cutting treatments in the seeding year'. Seed Sci. Technol. 10: 3-12.

Monirifar, H. (2011) 'Expected genetic gain for several quantitative traits in alfalfa (Medicago sativa L.)'. Not. Sci. Biol. 3: 109-113.

Popovic, S., Cupic ,T., Grljusic, S. and Tucak ,M.( 2006) 'Use of variability and path analysis in determining yield and quality of alfalfa. Proceeding of XXVI of the EUCARPIA Fodder Crops and Amenity Grasses Section'. Perugia, Italy, 95-99p.

Rincker, C.M., Marble, V.L., Brown, D. E, and Johansen, C.A. (1988) 'Seed production practices. In A.A. Hanson, D.K. Barnes, and R.R. Hill (eds): Alfalfa and Alfalfa improvement'. American Society of Agronomy Inc. Madison Wisconsin, pp. 985-1021.

Sengul, S.( 2006) 'Using path analysis to determine Lucerne (Medicago sativa L.) seed yield and its components'.
New Zealand Journal of Agricultural Research, 49: 107-115.

Suleyman, S. and Meryem, S. (2006) 'Determining Relationships Between Seed Yield and Yield Components in Alfalfa'. Pakistan Journal of Biological Sciences, 9: 1749-1753.

Steel, R.G.D., Torrie, J. H. and Dickey, D. A. (1997) 'Principles and procedures of statistics: A biometrical approach'. McGraw-Hill, New York.

Strbanovica,R.,Stanisavljevica,R.,Dukanovic a I, Postica, D., Markovicb, J., Gavrilovica, V. and Dolovac ,N.( 2015) 'Variability and Correlation of Yield and Forage Quality in Alfalfa Varieties of Different Origin. Tarım Bilimleri Dergisi'.- Journal of Agricultural Sciences, 23 (2017) 128137. 